Article

\title{
Pomegranate Fruit Quality and Seed Drying Method: Effect on the Chemical Composition and Bioactivities of the Extracted Oil
}

\author{
Olaniyi Amos Fawole ${ }^{1, *(D)}$, Tafadzwa Kaseke ${ }^{1}$ and Umezuruike Linus Opara ${ }^{2,3}$ (D) \\ 1 Postharvest Research Laboratory, Department of Botany and Plant Biotechnology, University of Johannesburg, \\ P.O. Box 524, Auckland Park, Johannesburg 2006, South Africa; tafakaseqe@gmail.com \\ 2 SARChI Postharvest Technology Research Laboratory, Africa Institute for Postharvest Technology, \\ Faculty of AgriSciences, Stellenbosch University, Stellenbosch 7602, South Africa; opara@sun.ac.za \\ 3 UNESCO International Centre for Biotechnology, Nsukka 410001, Nigeria \\ * Correspondence: olaniyif@uj.ac.za
}

check for updates

Citation: Fawole, O.A.; Kaseke, T.; Opara, U.L. Pomegranate Fruit Quality and Seed Drying Method: Effect on the Chemical Composition and Bioactivities of the Extracted Oil. Processes 2022, 10, 3. https://doi.org/ $10.3390 /$ pr10010003

Academic Editor: Yue Li

Received: 6 December 2021

Accepted: 20 December 2021

Published: 21 December 2021

Publisher's Note: MDPI stays neutral with regard to jurisdictional claims in published maps and institutional affiliations.

Copyright: (C) 2021 by the authors. Licensee MDPI, Basel, Switzerland. This article is an open access article distributed under the terms and conditions of the Creative Commons Attribution (CC BY) license (https:// creativecommons.org/licenses/by/ $4.0 /)$.

\begin{abstract}
The study presents a comparative investigation of the composition and bioactivity of oil extracted from pomegranate seeds of sun-burned fruit (SB) and healthy fruit (HF) for the valueadding potential of pomegranate fruit waste. Seeds from SB and HF were independently freeze dried, sun dried, and oven dried before ultrasound-assisted oil extraction using petroleum ether. The extracted oil was analysed for yield, refractive index, $\rho$-anisidine value, total phenolic content (TPC), DPPH radical scavenging ability, antimicrobial activity, tyrosinase enzyme inhibition ability, and fatty acid composition. The results showed that oven dried seeds, regardless of fruit quality, yielded the highest oil (20.85-24.70\%, dry weight). Regardless of the seed drying method, oil from the seeds of SB exhibited the highest TPC (1.48-2.84 mgGAE/g PSO) than oil from the seeds of HF. The oil from oven dried and freeze dried seeds of SB were more effective in scavenging the DPPH radicals with $\mathrm{IC}_{50}$ values of 34.77 and $39.97 \mu \mathrm{g} / \mathrm{mL}$, respectively. All the oil samples showed good ability to inhibit tyrosinase enzyme regardless of fruit quality and seed drying method, with monophenolase and diphenolase $\mathrm{IC}_{50}$ ranging between 0.31 and $0.49 \mathrm{mg} / \mathrm{mL}$ and 0.64 and $2.43 \mathrm{mg} / \mathrm{mL}$, respectively. Irrespective of the drying method, oil extracted from HF seeds exhibited greater antimicrobial potency against the tested bacteria. The fatty acid composition of the oil samples was neither affected by fruit quality and seed drying method. Generally, all oil samples exhibited high levels of punicic acid $(81.21-82.68 \%)$ and low omega 6 to omega 3 ratios $(0.19-0.37 \%)$, suggesting that the oil samples were healthy. Principal component analysis (PCA) established that freeze dried seeds of SB is an excellent source of oil with higher TPC, punicic acid, polyunsaturated fatty acids, and unsaturated fatty acid/saturated fatty acid ratio. It can be concluded that the seed from SB is a good raw material for oil that can be utilised in cosmetic products formulation.
\end{abstract}

Keywords: fruit; pomegranate seed oil; total phenolic content; antiradical activity; tyrosinase inhibition activity; fatty acid composition

\section{Introduction}

Pomegranates, well-known since ancient civilization, have become an important cash crop cultivated in various parts of the world [1]. Value added products, such as pomegranate jam, jelly, juice, syrup, vinegar, carbonated beverages, and wine, have emerged from the processing of fruit. Valorisation of pomegranates into these products generates substantial amounts of by-products, such as seeds and peels. Despite being underutilised, studies have shown that pomegranate seeds (PS) are considered a rich source of high quality oil (12-24\%), tocopherols, sterols, conjugated linolenic acids (mainly punicic acid), triterpenes, and phospholipids [2]. Literature has pointed out that pomegranate seed oil (PSO) possesses biological properties, such as antioxidant properties, estrogenic content immune function and lipid metabolism, antidiabetic property, lipoperoxidation, and skin photoaging 
inhibition [2-4]. Therefore, the utilisation of PSO is receiving special attention in the food, cosmetic, and nutraceutical industries.

Increasing consumer interest and awareness of pomegranate as a functional food has spurred a global increase in the production and consumption of fruit and its products. Pomegranate fruit has become one of the most important specialty crops in South Africa. About 1032 ha of pomegranate fruit is produced, along with an export volume of 6000 tonnes; South Africa is regarded as one of the major producers of pomegranate in the Southern Hemisphere, competing with countries such as Peru, Chile, and Argentina [5]. However, postharvest losses (20-40\%) limit the supply and consumption of pomegranate fruit, despite its high demand on both the local and export markets [5]. In pomegranates, quality deficiencies such as sunburns, bruises, cracks, and scalds render the fruit valueless as they are rejected on the local and export markets.

In South Africa, sunburn alone may inflict postharvest losses of up to $29 \%$ as the pomegranates become unmarketable at export and local markets [6,7]. Sunburn mostly occurs when the air temperature (in the shade) is above $30^{\circ} \mathrm{C}$ and fruit surface temperatures are above $45^{\circ} \mathrm{C}$ [8], leading to bleaching of the characteristic red colour of pomegranate aril, a term commonly known as the "cooking effect" [9]. This makes the fruit undesirable for processing into other products as colour is an important quality attribute for any pomegranate product. Such fruits are usually used as stockfeed or disposed of as waste, contributing to environmental problems. Postharvest losses resulting from sunburn not only constitute a significant revenue loss to farmers but also limit consumption of pomegranate products despite the ongoing global drive for safer, healthier, and sustainable diets [10]. From an economic perspective, the most effective way to add value to sun-burned pomegranate is to utilise the seeds for oil, which can be used as a functional ingredient in the cosmeceutical industry. In this regard, it is vital to investigate its biological properties to validate its potential application as a functional ingredient.

Despite PSO being a treasure of compounds with health benefits, the bioactive phytochemicals, contributing to the functionality of the oil, might be affected by the processes involved in oil production, such as seed drying. The effect of seed drying method on the extracted oil chemical properties has been reported in previous studies [11] Al Juhaimi et al. [12] reported that drying Kinnow mandarin, Eureka lemon, and Mandarin orange samples at $60^{\circ} \mathrm{C}$ for $24 \mathrm{~h}$ produced oil with the best DPPH radical scavenging capacity when compared to drying them at 70 and $80^{\circ} \mathrm{C}$ for $24 \mathrm{~h}$. Irondi et al. [13] compared air drying (room temperature), sun drying, oven drying, and freeze drying of papaya seeds and reported the highest, total phenolic content $(2.61 \mathrm{mg} / \mathrm{g})$, total flavonoid content $(0.52 \mathrm{mg} / \mathrm{g})$, total carotenoids content $(8.12 \mu \mathrm{g} / \mathrm{g})$, Trolox equivalent antioxidant capacity (TEAC) $(56.54 \mu \mathrm{M} \mathrm{TE} / \mathrm{g})$, ferric reducing antioxidant power (FRAP) (150.01 $\mu \mathrm{g}$ GAE/g) in oil extracted from freeze dried papaya seeds. Variation of oil quality with the seed drying method has also been reported with avocado, mango, and grape seeds [14-16]. Seed drying methods, which minimise nutritional quality and bioactive phytochemical losses, are desired by both PSO processors and consumers of the oil along the value chain.

Thus, the objective of the work described herein was to determine and compare the composition and biological properties of oil extracted from pomegranate seeds of SB and HF dried using different methods.

\section{Materials and Methods}

\subsection{Plant Material}

Healthy and sun-burned pomegranates ( $c v$. Acco) were manually harvested at commercial maturity (13.37-14.53 $3^{\circ}$ brix) in February 2014 season from a commercial farm in Western Cape, South Africa. The pomegranate seeds (PS) were separated from the juice using a cheesecloth, and thoroughly washed with distilled water to remove membranes and residues. 


\subsection{Seed Drying and Sample Preparation}

Clean PS from HF and SB were divided into three groups before they were freeze dried (VirTis Co., Gardiner, New York, NY, USA), oven dried $\left(40{ }^{\circ} \mathrm{C}\right)$ and sun dried to constant weights $(8-12 \% w / w)$. The dried samples were uniformly ground into powder $(<1 \mathrm{~mm}$ particle size $)$ and stored in airtight containers at $-80^{\circ} \mathrm{C}$ till further analysis.

\subsection{Oil Extraction}

PS $(5 \mathrm{~g})$ were mixed with petroleum ether $(50 \mathrm{~mL})$ in $500 \mathrm{~mL}$ plastic capped bottles, vortexed, before sonication at $40{ }^{\circ} \mathrm{C}$ for $60 \mathrm{~min}$ using an ultrasound bath (MRC Ltd., Holon, Israel). The sonicated samples were then centrifuged at $4000 \mathrm{rpm}$ for $5 \mathrm{~min}$ (Centrifuge 5810R, Eppendorf, Horsholm, Germany), after which the solvent was recovered under vacuum using a rotor vapor (G3 Heidolph, Schwabach, Germany). PSO extraction yield was defined as gram per hundred-gram pomegranate seed ( $\mathrm{g} / 100 \mathrm{~g}$ seed). The oil extraction was carried out in triplicates $(n=3)$.

\subsection{PSO Compositional Analysis}

\subsubsection{Refractive Index and $\rho$-Anisidine Value}

Refractive index $(\mathrm{RI})$ at $25^{\circ} \mathrm{C}$ was measured using a calibrated Abbe 5 refractometer (Bellingham + Stanley, Kent, UK). $\rho$-Anisidine value (AV) was determined following the AOCS official method [17].

\subsubsection{Preparation of PSO Extracts for Total Phenolic Content, Antiradical, and} Antimicrobial Activity

The extracts from PSO for analysing total phenolic content (TPC), and antiradical activity were prepared according to the method described by Jakopic et al. [18] with minor modifications. Triplicated PSO samples $(1 \mathrm{~g})$ were independently mixed with $10 \mathrm{~mL}$ of distilled water, $50 \%$ aqueous ethanol, and 100\% ethanol, vortexed, and sonicated, before centrifugation at $4000 \mathrm{rpm}$ for $10 \mathrm{~min}$. The collected supernatant was stored at $-20^{\circ} \mathrm{C}$ until analysis.

\subsubsection{Total Phenolic Content}

The reaction mixture contained $100 \mu \mathrm{L}$ of PSO extracts, $500 \mu \mathrm{L}$ of the Folin-Ciocalteau reagent and $1.5 \mathrm{~mL}$ of $2 \%(w / v)$ sodium carbonate and $6 \mathrm{~mL}$ of distilled water. The samples were incubated in the dark for $30 \mathrm{~min}$ and their absorbance measured at $760 \mathrm{~nm}$ with a UV spectrophotometer (Helios Omega, Thermo Scientific, Waltham, MA, USA). Gallic acid standard curve $\left(0.0-20 \mu \mathrm{g} / \mathrm{mL} ; \mathrm{R}^{2}\right.$ 0.9852) was used, and total phenolic content was expressed as milligram gallic acid equivalent per mL PSO (mg GAE/mL PSO).

\subsubsection{Radical Scavenging Activity}

The antiradical activity of PSO was measured using the unstable radical, 2,2-diphenyl1-picrylhydrazyl (DPPH) as a reagent according to the method used by Fawole and Opara [19]. In brief, $80 \%$ of DPPH in methanol was prepared and $750 \mu \mathrm{L}$ of the solution was mixed with $15 \mu \mathrm{L}$ of the PSO extracts containing $0.00-100 \mu \mathrm{g} / \mathrm{mL}$ oil and ascorbic acid. Ascorbic acid was used as a positive control. The mixture was vortexed and incubated at room temperature for $1 \mathrm{~h}$ in the dark, and the decrease in absorbance of DPPH was measured at $517 \mathrm{~nm}$ using a UV spectrophotometer (Helios Omega, Thermo Scientific, Waltham, MA, USA). The ability of the oil to scavenge DPPH radical was calculated as \% inhibition using the equation below:

$$
\% \text { Inhibition }=\left[\left(\mathrm{Abs}_{\mathrm{control}}-\mathrm{Abs}_{\text {sample }}\right)\right] /\left(\mathrm{Abs}_{\text {control }}\right) \times 100
$$

The sample concentration providing $50 \%$ inhibition $\left(\mathrm{IC}_{50}\right)$ was calculated by plotting the inhibition percentages against the concentrations of the sample. 


\subsubsection{Tyrosinase Inhibition Determination}

Tyrosinase inhibition was determined following a previous method [1]. Samples were dissolved in dimethyl sulfoxide (DMSO) to a concentration of $20 \mathrm{mg} / \mathrm{mL}$, and further diluted in potassium phosphate buffer $(50 \mathrm{mM}, \mathrm{pH}$ 6.5) to $600 \mu \mathrm{g} / \mathrm{mL}$. Assays were carried out at room temperature and in a 96-well micro-titre plate using a Multiskan FC plate reader (Thermo scientific technologies, China). In triplicate, each prepared sample $(70 \mu \mathrm{L})$ was mixed with $30 \mu \mathrm{L}$ of tyrosinase (333 Units $/ \mathrm{mL}$ in phosphate buffer, $\mathrm{pH}$ 6.5). After $5 \mathrm{~min}$ incubation, $110 \mu \mathrm{L}$ of the substrate ( $2 \mathrm{mM}$ L-tyrosine or $12 \mathrm{mM}$ L-DOPA) was added to the reaction mixtures and incubated further for $30 \mathrm{~min}$. The final concentration of the PSO was between $2.6-333.3 \mu \mathrm{g} / \mathrm{mL}$. Arbutin $(1.04-133.33 \mu \mathrm{g} / \mathrm{mL})$ was used as a positive control. Absorbance values were determined at $492 \mathrm{~nm}$. The percentage tyrosinase inhibition was calculated as follows:

$$
\% \text { inhibition }=\left[\left(A_{\text {control }}-A_{\text {sample }}\right) / A_{\text {control }}\right] \times 100
$$

where $\mathrm{A}_{\text {control }}$ is the absorbance of DMSO and $\mathrm{A}_{\text {sample }}$ is the absorbance of the test reaction mixture containing PSO or arbutin. The $\mathrm{IC}_{50}$ values of PSO and arbutin were calculated.

\subsubsection{Antibacterial Determination}

The method described by Fawole et al. [1] was used to determine the antibacterial activity of the oil samples. The activity was tested against two Gram-positive bacterial strains (Bacillus subtilis ATCC 6051 and Staphylococcus aureus ATCC 12600) and two Gram-negative bacteria (Escherichia coli ATCC 11,775 and Klebsiella pneumonia ATCC 13883). Cultures were grown overnight in sterile Mueller-Hinton $(\mathrm{MH})$ broth, and a $0.5 \mathrm{McF}$ arland absorbance at $600 \mathrm{~nm}$ was used as a reference. The initial concentration $(50 \mathrm{mg} / \mathrm{mL})$ of oil samples was prepared by resuspending the oil samples in methanol. In triplicate, the resuspended oil samples $(100 \mu \mathrm{L}$ per well) were serially diluted with sterile distilled water in a 96-wellmicroplate, followed by the addition of $100 \mu \mathrm{L}$ bacterial suspension to each well. One positive antibiotic control $(0.1 \mathrm{mg} / \mathrm{mL}$ Streptomycin; Sigma-Aldrich, Saint Louis, MO, USA), one negative control (sterile distilled water) and blank control (aqueous methanol) were set up against each bacterium. The final concentration of reconstituted PSO in the 96-well-microplate ranged from 0.097 to $12.5 \mathrm{mg} / \mathrm{mL}$, and streptomycin concentrations ranged from 0.01 to $0.5 \mathrm{mg} / \mathrm{mL}$ in each respective well. The microplates were incubated at $37^{\circ} \mathrm{C}$ for $18 \mathrm{~h}$ before $40 \mu \mathrm{L}$ of p-iodonitrotetrazolium chloride (INT; Sigma-Aldrich, Darmstadt, Germany) was added to each well. These plates were further incubated for $1 \mathrm{~h}$ and were examined thereafter. Bacterial growth/survival was clearly visible as these wells turned pink. The clear wells indicated the inhibition of bacterial growth, and thus the minimum inhibitory concentration (MIC) values were recorded as the concentrations in the last wells in which no colour change was observed after adding INT indicator.

\subsubsection{Fatty Acids}

Briefly, pomegranate seed oil $(0.1 \mathrm{~g})$ was weighed into $15 \mathrm{~mL}$ glass vials followed by the addition of $2.0 \mathrm{~mL}$ hexane, $50 \mu \mathrm{L}$ heptadecanoic acid $1000 \mathrm{ppm}$, internal standard) and $1.0 \mathrm{~mL}$ of $20 \%(v / v) \mathrm{H}_{2} \mathrm{SO}_{4}$ in methanol. The reaction mixture was vortexed and incubated at $80{ }^{\circ} \mathrm{C}$ for $1 \mathrm{~h}$ in an oven. The mixture was cooled, and then $3 \mathrm{~mL}$ of saturated $\mathrm{NaCl}$ was added, vortexed, and centrifuged [20]. The fatty acid methyl esters (FAME) were then separated on a GC-MS system (6890N, Agilent technologies network) that was coupled to an Agilent technologies inert XL EI/CI Mass Selective Detector (MSD) (5975B, Agilent Technologies Inc., Palo Alto, CA, USA). Helium, the carrier gas, was applied at a flow rate of $0.017 \mathrm{~mL} / \mathrm{s}$, and $1 \mu \mathrm{L}$ of the sample was injected using a split ratio of 10:1. The oven temperature was programmed as follows: $100{ }^{\circ} \mathrm{C} / \mathrm{min}, 180^{\circ} \mathrm{C}$ at $25^{\circ} \mathrm{C} / \mathrm{min}$ and held for $3 \mathrm{~min}, 200{ }^{\circ} \mathrm{C}$ at $4{ }^{\circ} \mathrm{C} / \mathrm{min}$ and held for $5 \mathrm{~min}, 280{ }^{\circ} \mathrm{C}$ at $8{ }^{\circ} \mathrm{C} / \mathrm{min}$, and $310{ }^{\circ} \mathrm{C}$ at $10^{\circ} \mathrm{C} / \mathrm{min}$ and held for $5 \mathrm{~min}$. The mass spectrometer was operated under electron impact mode at ionization energy of $70 \mathrm{eV}$, scanning from 35 to $500 \mathrm{~m} / \mathrm{z}$. The pomegranate seed 
oil fatty acids profiles were identified by comparing their retention times with those of FAME standards (cis-oleic acid, palmitic acid, stearic acid, margaric acid, arachidic acid, behenic acid, trans-oleic acid, $\gamma$-linolenic acid, and $\alpha$-linolenic acid) purchased from Sigma, South Africa. The relative content (\%) of each fatty acid was calculated by dividing the peak area of each fatty acid by the total peak area of all the fatty acids identified, excluding minor constituents.

\subsection{Statistical Analysis}

All data are presented as mean values ( \pm S.D) (standard deviation) from triplicate samples. Two-way (factor A-fruit quality and factor B-seed drying method) and oneway analysis of variance (ANOVA) were performed using Statistica software (Statistical v13, TIBC, Palo Alto, CA, USA, and the mean values were separated using Duncan's multiple range test $(p<0.05)$. Graphical presentations were made using Microsoft Excel (Version: 16.0.13029.20344, Microsoft Cooperation, Washington, DC, USA). The relationship between fruit quality, seed drying method and oil chemical properties was determined by performing principal component analysis (PCA) using Microsoft excel software (XLSTAT 2019.4.1.63305, Addinsoft, New York, NY, USA).

\section{Results and Discussion}

\subsection{Oil Yield}

Oil yield is a critical parameter in seed oil processing as it is directly proportional to the gross income. As shown in Figure 1, there was a combined effect of fruit quality and seed drying method on oil yield ( $p=0.005$ ). The oil yield varied between 17.35 and $24.70 \%$ (dry weight) (dw) with oven dried seeds, both from SB (20.85\%) and HF (24.70\%), exhibiting the highest oil yield. The findings suggest that oven drying of pomegranate seeds prior to oil extraction could be a desirable method for maximising the release of lipids from the oleaginous material. The lowest oil yield was shown by sun dried seeds from both HF (17.55\%) and SB (17.35\%). The oil yield results in the present study were higher than those reported by Ahangari et al. [21] (12.02-17.12\%) and Tian et al. [22] (15.72\%) from propane and supercritical carbon dioxide extraction, respectively. The observed discrepancies could be attributed to genetic factors, seed drying method, and oil extraction technique. The high oil yield results in the present study, irrespective of fruit quality, makes the seeds from SB a good raw material for the PSO industry. The results from other researchers confirm that the seed drying method significantly affects oil yield. Omosuli et al. [23] reported a 28\% variation in yield of Soxhlet extracted oil from sun-dried (32.21\%) and cabinet dried (33.11\%) moringa seeds. In another study, a 1.1 fold difference in oil yield after Soxhlet extraction was observed between sun-dried $(40.28 \%)$ and oven dried (43.32\%) watermelon seeds [24].

\subsection{Refractive Index and $\rho$-Anisidine Value}

The results showed that neither fruit quality nor seed drying method had a significant effect on the extracted oil refractive index $(p>0.05)$ (Table 1$)$. The findings suggest no significant changes to the fatty acid profiles among the samples. The RI values narrowly varied between 1.4900 and 1.4990 and were comparable to those reported by Khoddami et al. [25] (1.4977-1.4983) from three different pomegranate cultivars (TMOI, COI, and COT). Hydroperoxides formed from the primary oxidation of fatty acids during oil processing further degrades to produce secondary products, including aldehydes and ketones. The concentration of these carbonyl compounds in seed oil can be determined by measuring the $\rho$-anisidine value. Statistical analysis showed that there was an insignificant $(p>0.05)$ interaction between fruit quality and seed drying method on the extracted oil $\rho$-anisidine value (Table 1$)$. Freeze drying is recognised as a good method to protect heat labile components in the drying process. However, highest AVs were exhibited by oil from freeze dried seeds (4.65-4.80), whilst the oil from oven dried seeds showed the lowest AVs (2.18-2.65), regardless of the quality of the fruit. This may be partly explained by the retention of lipoxygenase enzyme because of lower temperature employed during freeze drying. Similar findings were reported with oil from freeze dried flaxseed and 
pumpkin seed [26,27]. Nonetheless, other studies reported different results. Jahurul et al. [28] reported that AV of oil from oven dried rambutan (Nephelium lappaceum L.) seeds was 1.4-fold higher than that of oil from freeze dried seeds. The low levels of carbonyl compounds in the oil from freeze dried seeds could be ascribed to the absence of heat during drying [28].

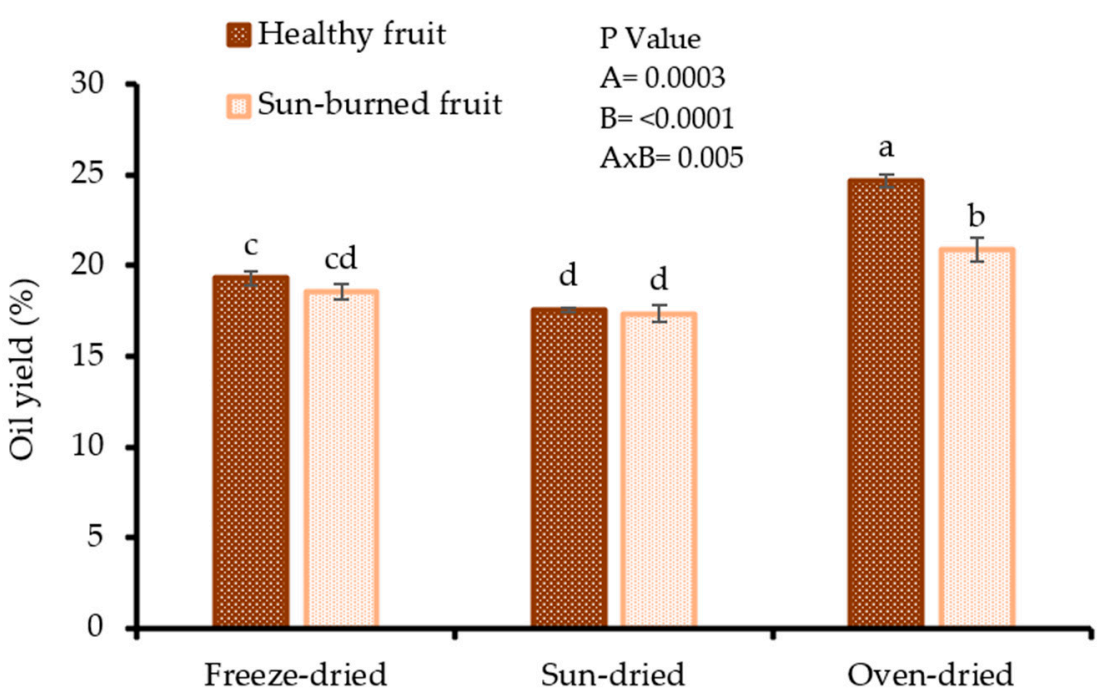

Figure 1. Oil yield from seeds of healthy and sun-burned fruits and dried under different drying methods. Factorial ANOVA was performed for Factor A (fruit quality), and Factor B (seed drying method). Columns followed by different letters are significantly different $(p<0.05)$ according to Duncan's multiple range test. Vertical bars indicate the standard deviation of the mean.

Table 1. Refractive index (RI), anisidine value (AV), DPPH radical scavenging ability, and tyrosinase enzyme inhibition of oil from seeds of healthy and sun burned fruit and dried under different drying methods.

\begin{tabular}{|c|c|c|c|c|c|c|}
\hline $\begin{array}{l}\text { Seed Drying } \\
\text { Method }\end{array}$ & $\begin{array}{c}\text { Fruit } \\
\text { Quality }\end{array}$ & $\mathrm{RI}\left(25^{\circ} \mathrm{C}\right)$ & AV & $\begin{array}{c}\text { DPPH } \\
\left(\mathrm{IC}_{50}\right)(\mu \mathrm{g} / \mathrm{mL})\end{array}$ & $\begin{array}{l}\text { Monophenolase } \\
\left(\mathrm{IC}_{50}\right)(\mu \mathrm{g} / \mathrm{mL})\end{array}$ & $\begin{array}{c}\text { Diphenolase } \\
\left(\mathrm{IC}_{50}\right)(\mu \mathrm{g} / \mathrm{mL})\end{array}$ \\
\hline \multirow[t]{2}{*}{ Freeze-dried } & Healthy & $1.4990 \pm 0.0000^{\mathrm{a}}$ & $4.80 \pm 2.03^{a}$ & $59.29 \pm 1.91^{\mathrm{a}}$ & $0.49 \pm 0.074^{\mathrm{a}}$ & $0.68 \pm 0.046^{c}$ \\
\hline & Sun-burned & $1.4920 \pm 0.0000^{\mathrm{a}}$ & $4.65 \pm 0.60^{a}$ & $39.97 \pm 2.37^{b c}$ & $0.33 \pm 0.040^{b}$ & $2.43 \pm 0.543^{\mathrm{a}}$ \\
\hline \multirow[t]{2}{*}{ Sun-dried } & Healthy & $1.4982 \pm 0.0000^{\mathrm{a}}$ & $3.25 \pm 0.85^{\mathrm{a}}$ & $56.65 \pm 2.40^{a}$ & $0.33 \pm 0.032^{b}$ & $1.80 \pm 0.550 \mathrm{ab}$ \\
\hline & Sun-burned & $1.4902 \pm 0.0000^{\mathrm{a}}$ & $2.75 \pm 0.60^{a}$ & $51.98 \pm 5.88^{a b}$ & $0.31 \pm 0.001^{b}$ & $0.94 \pm 0.328^{b c}$ \\
\hline \multirow[t]{2}{*}{ Oven-dried } & Healthy & $1.4988 \pm 0.0000^{\mathrm{a}}$ & $2.18 \pm 0.08^{a}$ & $47.03 \pm 3.77^{a b c}$ & $0.35 \pm 0.014^{b}$ & $0.64 \pm 0.056^{b c}$ \\
\hline & Sun-burned & $1.4900 \pm 0.0000^{\mathrm{a}}$ & $2.67 \pm 0.12^{a}$ & $34.77 \pm 3.56^{c}$ & $0.36 \pm 0.008^{b}$ & $0.68 \pm 0.047^{b c}$ \\
\hline $\begin{array}{c}\text { Ascorbic acid } \\
\text { Arbutin }\end{array}$ & & & & $0.99 \pm 0.027$ & $0.04 \pm 0.001$ & $0.01 \pm 0.001$ \\
\hline \multicolumn{7}{|c|}{ Significance Level } \\
\hline Fruit condition (A) & & 0.312 & 0.646 & 0.006 & 0.087 & 0.289 \\
\hline Drying method (B) & & 0.421 & 0.122 & 0.025 & 0.101 & 0.054 \\
\hline $\mathrm{AxB}$ & & 0.811 & 0.979 & 0.203 & 0.106 & 0.008 \\
\hline
\end{tabular}

Factorial ANOVA was performed for Factor A (seed drying method) and Factor B (fruit quality). Columns followed by different letters are significantly different $(p<0.05)$ according to Duncan's multiple range test. Values are means \pm SD of triplicate determinations. Means in the same column and followed by different letters are significantly different $(p \leq 0.05)$ according to Duncan's multiple range test. RI: refractive index, AV: anisidine value, and DPPH: 2,2-diphenyl-1-picryl hydrazyl.

\subsection{Total Phenolic Content and Antiradical Activity}

The results from Figure 2 indicate that the variation of total phenolic content in oil samples resulted from the mutual effect of fruit quality and seed drying method ( $p=0.0022)$. However, oil from SB seeds exhibited higher total phenolic content $(2.84,1.60$, and $1.40 \mathrm{mg}$ GAE/g PSO for freeze dried, sun-dried, and oven dried seeds, respectively), regardless of the drying method. The result that oil from freeze dried seeds showed the highest total phenolic content 
(1.3-2.0 times higher) compared with oil from sun-dried and oven dried seeds, indicates that the applied seed drying methods had a significant effect on the extraction of phenolic content. Maximum extraction of the phenolic content from the seed matrix is desired by oil consumers such as cosmetic products manufacturers as these bioactive phytochemicals have been implicated in the functionality of PSO. The TPC (0.75-2.84 mgGAE/g PSO) values in the present study were higher than those reported by Pande and Akoh [29] (0.85-0.91 mg/g PSO) and Costa et al. [30] (0.00-0.17 mg/g PSO) from solvent extracted, and cold pressed PSO. Among other factors, the differences observed could be due to variation in cultivar, seed drying method, oil extraction technique, and fruit growing region. Nonetheless, the TPC results were lower than those from other fruit seed oil such as papaya (10.66-13.29 mgGAE/g oil) and avocado (25.72-70.19 mgGAE/g oil) [31,32].

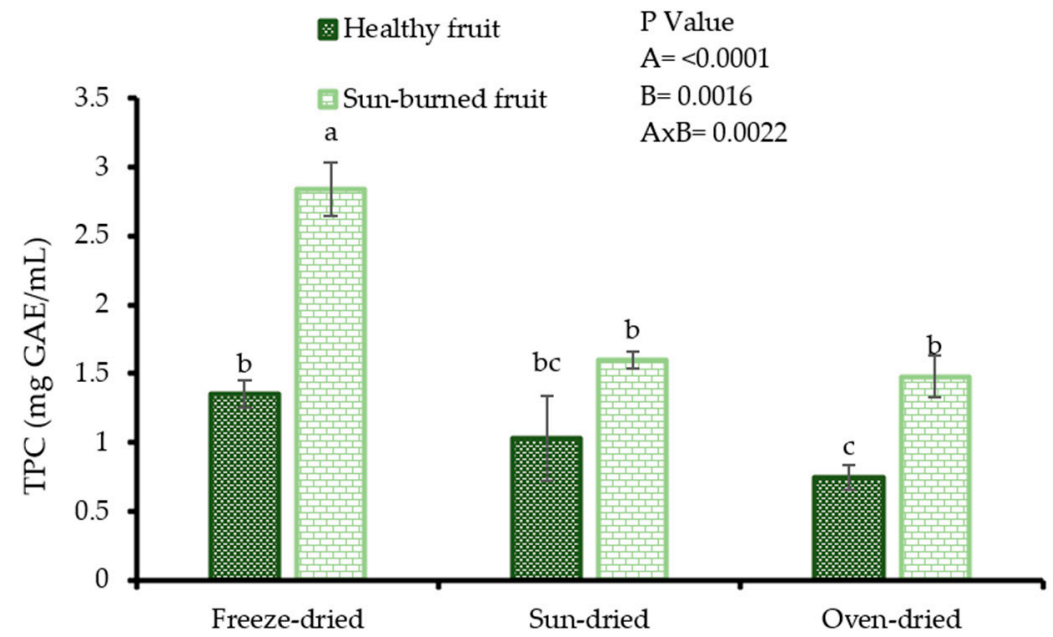

Figure 2. Total phenolic content (TPC) of oil from seeds of healthy and sun-burned fruits and dried under different drying methods. Factorial ANOVA was performed for Factor A (fruit quality) and Factor B (seed drying method). Columns followed by different letters are significantly different $(p<0.05)$ according to Duncan's multiple range test. Vertical bars indicate the standard deviation of the mean.

The DPPH assay has been used widely to evaluate the antiradical activity of plant extracts, including seed oil. The $\mathrm{IC}_{50}$ value indicates the concentration of sample required to scavenge 50\% DPPH free radicals [33]. As shown in Table 1, both fruit quality $(p=0.006)$ and seed drying method $(p=0.025)$ significantly affected the extracted oil DPPH radical scavenging capacity. Despite this, their combined effect was insignificant. The oil from oven dried and freeze dried seeds of SB were more effective in scavenging the DPPH radicals with $\mathrm{IC}_{50}$ values of 34.77 and $39.97 \mu \mathrm{g} / \mathrm{mL}$, respectively. This indicates that $\mathrm{SB}$ is a potential raw material for oil that could be applied in the formulation of cosmetic products.

On the other hand, oil from sun-dried and freeze dried seeds of HF showed the lowest $\mathrm{DPPH}$ radicals scavenging ability $\left(\mathrm{IC}_{50}: 56.56\right.$ and $59.29 \mu \mathrm{g} / \mathrm{mL}$, respectively). The greater DPPH radical scavenging capacity of oil from oven dried and freeze dried seeds of SB could be due to higher total phenolic compounds reported in the respective oil samples. The contribution of total phenolics to oil antioxidant properties has been highlighted in literature [11,34]. Moreover, other antioxidant compounds such as tocopherols present in PSO have been implicated in the oil antiradical activity [35]. The DPPH radical scavenging capacity of the oil samples was lower than that of ascorbic acid, a standard antioxidant (Table 1).

\subsection{Tyrosinase Inhibition and Antimicrobial Activity}

Tyrosinase enzyme catalyses the biosynthesis of melanin, which plays an important role in protecting the skin from ultraviolet radiation. On the other hand, increased melanin levels may result in skin pigmentation disorders, such as melasma and age spots [36]. In line with this, tyrosinase inhibitors can be useful for the prevention of dermatological disorders linked to excessive concentration of melanin [36]. As shown in Table 1, the ability of the oil 
samples to inhibit both monophenolase and diphenolase activity was neither influenced by fruit quality nor seed drying method $(p>0.05)$. Except for the oil from freeze dried seeds of $\mathrm{HF}\left(\mathrm{IC}_{50}: 0.49 \mu \mathrm{g} / \mathrm{mL}\right)$, all other oil samples showed similar inhibition of monophenolase $\left(\mathrm{IC}_{50}: 0.31-0.36 \mu \mathrm{g} / \mathrm{mL}\right.$ ). Regarding diphenolase activity inhibition, the $\mathrm{IC}_{50}$ of the oil samples varied from $0.64-2.43 \mu \mathrm{g} / \mathrm{mL}$, with oil from oven dried seeds showing the greatest inhibitory activity (Table 1). However, the studied oil samples showed lower tyrosinase enzyme inhibition activity than arbutin, a known standard enzyme inhibitor $(0.04$ and $0.01 \mu \mathrm{g} / \mathrm{mL}$ for monophenolase and diphenolase activity, respectively). Overall, the oil samples showed better monophenolase activity inhibition than diphenolase activity. The inhibition of tyrosinase enzyme activity in the present study could be attributed to the ability of phenolics to chelate the copper ion in the active site, leading to irreversible inactivation of tyrosinase [36].

The antimicrobial activity of the oil samples on the studied microorganisms is presented in Table 2 . The oil samples exhibited a broad-spectrum activity against the bacterial strains used. Regardless of the drying method, oil extracted from HF seeds, exhibited greater antimicrobial potency against both the Gram negative (Escherichia coli and Klebsiella pneumonia) and Gram positive bacteria (Bacillus subtilis and Staphylococcus aureus) with MIC ranging from 1.56 to $12.5 \mathrm{mg} / \mathrm{mL}$. On the other hand, oil extracted from seeds of SB showed lower antimicrobial activity against the bacteria with minimum inhibitory concentration (MIC) ranging from $12.5 \mathrm{mg} / \mathrm{mL}$ and above, despite showing greater tyrosinase inhibition. The phenolics in pomegranate seed oil have been implicated in its antimicrobial activity through enzymatic inhibition of the oxidised compound or reacting with sulfhydryl groups of proteins via non-specific modes, modifying protein functionality [37]. However, all the oil samples showed lower antimicrobial activity than Streptomycin $(<0.0195 \mathrm{mg} / \mathrm{mL})$ (Table 2). Studies on the antimicrobial activity of pomegranate seed oil are scarce in the literature. Oil from pomegranate seeds showed better antimicrobial activity against the same bacteria than other seed oil. For instance, Alqahtani et al. [38] reported higher MIC (47.5-95 mg/mL) of garden cress (Lepidium sativum) seed oil on Escherichia coli, Klebsiella pneumonia, Bacillus subtilis, and Staphylococcus aureus.

Table 2. Antimicrobial activity (MIC, $\mathrm{mg} / \mathrm{mL}$ ) of oil from seeds of healthy and sun-burned fruits and dried under different drying methods.

\begin{tabular}{cccccc}
\hline & \multicolumn{2}{c}{ Gram Positive } & \multicolumn{2}{c}{ Gram Negative } \\
\hline Seed Drying Method & Fruit Quality & $\begin{array}{c}\text { Bacillus } \\
\text { Subtilis }\end{array}$ & $\begin{array}{c}\text { Staphylococus } \\
\text { Aureus }\end{array}$ & $\begin{array}{c}\text { Escherichia } \\
\text { Coli }\end{array}$ & $\begin{array}{c}\text { Klebsiella } \\
\text { Pneumonia }\end{array}$ \\
\hline Freeze-dried & Healthy & 6.25 & 6.25 & 12.5 & 1.563 \\
& Sun-burned & 12.5 & $>12.50$ & 12.5 & $>12.50$ \\
Sun-dried & Healthy & 3.125 & 6.25 & 3.125 & $>12.5$ \\
& Sun-burned & $>12.50$ & $>12.50$ & 6.25 & 12.50 \\
Oven-dried & Healthy & 6.25 & 3.125 & $>12.5$ & $>12.5$ \\
& Sun-burned & $>12.5$ & 6.25 & $<0.0195$ & $<0.0195$ \\
\hline
\end{tabular}

\subsection{Fatty Acid Composition}

Fatty acid composition is one of the essential quality characteristics of oilseed crops, as it determines the nutritional and industrial application of the oil. Fatty composition of the oil extracted from seeds of HF and SB dried using different methods are presented in Table 3. The key fatty acids were punicic acid, cis-oleic acid, palmitic acid, and stearic acid, representing $81.21-82.68 \%, 6.78-7.75 \%, 4.68-5.04 \%, 1.60-1.82 \%$, respectively, of the total fatty acids. Other fatty acids present in minor quantities were margaric acid, arachidic acid, behenic acid, trans-oleic acid, $\gamma$-linolenic acid, and $\alpha$-linolenic acid, and varied between 0.12 and $1.50 \%$. Generally, the fatty acid composition of pomegranate seed oil was not affected by both fruit quality and seed drying method, suggesting similarities in the fatty 
acid composition of all the oil samples. The finding that seed drying method had an insignificant effect on the fatty acid compositions was comparable to the results reported by Zhang et al. [27], who investigated the effect of vacuum drying, microwave drying, oven drying and freeze drying flaxseed on the quality of extracted oil. Regarding fruit quality effect, Zaouay et al. [39] reported that the oil fatty acid composition of seed from intact and cracked pomegranates significantly differed.

Table 3. Fatty acid composition (\%) of oil from seeds of healthy and sun-burned fruits and dried under different drying methods.

\begin{tabular}{|c|c|c|c|c|c|c|}
\hline Fatty Acids & FDH & FD-SB & SDH & SD-SB & ODH & OD-SB \\
\hline \multicolumn{7}{|l|}{ SFA } \\
\hline Palmitic acid (C16:0) & $4.95 \pm 0.022^{\mathrm{ab}}$ & $4.68 \pm 0.006^{c}$ & $5.04 \pm 0.025^{a b}$ & $4.90 \pm 0.040^{\mathrm{b}}$ & $5.08 \pm 0.014^{\mathrm{a}}$ & $4.98 \pm 0.087^{\mathrm{ab}}$ \\
\hline Margaric acid (C17:0 & $1.18 \pm 0.006^{\mathrm{a}}$ & $1.50 \pm 0.395^{\mathrm{a}}$ & $1.03 \pm 0.041^{\mathrm{a}}$ & $1.03 \pm 0.065^{\mathrm{a}}$ & $1.03 \pm 0.011^{\mathrm{a}}$ & $1.06 \pm 0.061^{\mathrm{a}}$ \\
\hline Stearic acid (C18:0) & $1.73 \pm 0.023^{\mathrm{ab}}$ & $1.64 \pm 0.005^{\mathrm{ab}}$ & $1.60 \pm 0.026^{\mathrm{b}}$ & $1.67 \pm 0.117^{\mathrm{ab}}$ & $1.82 \pm 0.010^{\mathrm{ab}}$ & $1.72 \pm 0.024^{\mathrm{a}}$ \\
\hline Arachidic acid (C20:0) & $0.39 \pm 0.001^{\mathrm{b}}$ & $0.37 \pm 0.001^{c}$ & $0.39 \pm 0.005^{b c}$ & $0.38 \pm 0.009 \mathrm{bc}$ & $0.41 \pm 0.004^{a}$ & $0.38 \pm 0.001 \mathrm{bc}$ \\
\hline Behenic acid (C22:0) & $0.20 \pm 0.005^{\mathrm{a}}$ & $0.14 \pm 0.017^{b}$ & $0.15 \pm 0.009^{b}$ & $0.13 \pm 0.006^{b}$ & $0.12 \pm 0.005^{b}$ & $0.13 \pm 0.006^{b}$ \\
\hline \multicolumn{7}{|l|}{ MUFA } \\
\hline $\begin{array}{l}\text { cis-Oleic acid } \\
\text { (C18:1 n-9 cis) }\end{array}$ & $6.78 \pm 0.032^{d}$ & $7.25 \pm 0.100^{b c}$ & $7.07 \pm 0.08^{c d}$ & $7.17 \pm 0.14 \mathrm{~b}^{\mathrm{c}}$ & $7.45 \pm 0.028^{a b}$ & $7.76 \pm 0.117^{\mathrm{a}}$ \\
\hline $\begin{array}{l}\text { trans-Oleic acid } \\
(\mathrm{C} 18: 1 \mathrm{n}-9 \text { trans) }\end{array}$ & $0.41 \pm 0.003^{\mathrm{a}}$ & $0.40 \pm 0.017^{\mathrm{a}}$ & $0.43 \pm 0.002^{\mathrm{a}}$ & $0.42 \pm 0.02^{\mathrm{a}}$ & $0.41 \pm 0.004^{\mathrm{a}}$ & $0.41 \pm 0.008^{\mathrm{a}}$ \\
\hline \multicolumn{7}{|l|}{ PUFA } \\
\hline $\begin{array}{c}\gamma \text {-Linolenic acid } \\
(\text { C18:3 n-6) }\end{array}$ & $0.20 \pm 0.008^{a}$ & $0.18 \pm 0.005^{b}$ & $0.18 \pm 0.006^{\mathrm{b}}$ & $0.20 \pm 0.006^{\mathrm{a}}$ & $0.20 \pm 0.003^{a b}$ & $0.21 \pm 0.005^{\mathrm{a}}$ \\
\hline $\begin{array}{l}\text { Punicic acid (cis-9, } \\
\text { trans-11, cis-13 C18:3) }\end{array}$ & $81.21 \pm 0.275^{c}$ & $82.46 \pm 0.538^{a b}$ & $82.51 \pm 0.158^{a b}$ & $82.68 \pm 0.172^{a}$ & $81.64 \pm 0.028^{a b c}$ & $81.52 \pm 0.294^{b c}$ \\
\hline $\begin{array}{c}\alpha \text {-Linolenic acid } \\
(C 18: 3 n-3)\end{array}$ & $0.72 \pm 0.006^{c}$ & $0.78 \pm 0.017^{b c}$ & $0.91 \pm 0.018^{b}$ & $0.55 \pm 0.011^{\mathrm{d}}$ & $0.90 \pm 0.002^{b}$ & $1.07 \pm 0.083^{\mathrm{a}}$ \\
\hline$\sum$ SFA & $8.45 \pm 0.06^{\mathrm{a}}$ & $8.32 \pm 0.41^{\mathrm{a}}$ & $8.20 \pm 0.09^{a}$ & $8.12 \pm 0.08^{a}$ & $8.46 \pm 0.02^{\mathrm{a}}$ & $8.27 \pm 0.18^{a}$ \\
\hline$\sum$ MUFA & $7.18 \pm 0.04^{d}$ & $7.66 \pm 0.08 b^{c}$ & $7.50 \pm 0.08^{\mathrm{bd}}$ & $7.58 \pm 0.14^{\mathrm{bc}}$ & $7.86 \pm 0.03^{\mathrm{ac}}$ & $8.17 \pm 0.13^{a}$ \\
\hline$\sum$ PUFA & $82.13 \pm 0.26^{b}$ & $83.42 \pm 0.55^{\mathrm{a}}$ & $83.59 \pm 0.17^{\mathrm{a}}$ & $83.43 \pm 0.16^{\mathrm{a}}$ & $82.74 \pm 0.03^{a b}$ & $82.81 \pm 0.21 \mathrm{ab}$ \\
\hline$\sum$ MUFA/PUFA ratio & $0.09 \pm 0.00^{c}$ & $0.09 \pm 0.00^{b c}$ & $0.09 \pm 0.00^{c}$ & $0.09 \pm 0.00 \mathrm{bc}$ & $0.09 \pm 0.00^{\mathrm{ab}}$ & $0.10 \pm 0.00^{\mathrm{a}}$ \\
\hline$\sum$ UFA/SFA ratio & $10.57 \pm 0.04^{\mathrm{a}}$ & $10.98 \pm 0.60^{\mathrm{a}}$ & $11.11 \pm 0.13^{\mathrm{a}}$ & $11.21 \pm 0.11^{\mathrm{a}}$ & $10.71 \pm 0.02^{\mathrm{a}}$ & $11.01 \pm 0.25^{\mathrm{a}}$ \\
\hline \multirow[t]{2}{*}{$\omega 6 / \omega 3$ ratio } & $0.28 \pm 0.01^{\mathrm{a}}$ & $0.23 \pm 0.01^{\mathrm{c}}$ & $0.19 \pm 0.00^{\mathrm{d}}$ & $0.37 \pm 0.01^{b}$ & $0.22 \pm 0.00^{\mathrm{cd}}$ & $0.20 \pm 0.01^{\mathrm{d}}$ \\
\hline & $\begin{array}{l}\text { Values } \\
\text { letters } \\
\text { MUFA- } \\
\text { dried s } \\
\text { FD-SB- } \\
\text { seed fro }\end{array}$ & $\begin{array}{l}\text { neans } \pm \text { SD of tri } \\
\text { ignificantly differ } \\
\text { ounsaturated fatt } \\
\text { rom healthy frui } \\
\text { un-burned fruit, } \\
\text { un seed fron }\end{array}$ & $\begin{array}{l}\text { ate determination } \\
t(p<0.05) \text { accord } \\
\text { cids, PUFA-polyu } \\
\text { DH-sun dried see } \\
\text { an-burned fruit, } S\end{array}$ & $\begin{array}{l}\text { Means in the sam } \\
\text { to Duncan's mu } \\
\text { turated fatty acic } \\
\text { rom healthy frui } \\
\text { B-sun dried seed }\end{array}$ & $\begin{array}{l}\text { W and followed by } \\
\text { le range test. SFA- } \\
\text { JFA-unsaturated fa } \\
\text { DH-oven dried fru } \\
\text { m sun-burned fru }\end{array}$ & $\begin{array}{l}\text { ifferent superscrip } \\
\text { turated fatty acid } \\
\text { acids, FDH-freez } \\
\text { from healthy frui } \\
\text { OD-SB-oven driec }\end{array}$ \\
\hline
\end{tabular}

The saturated fatty acids (SFAs) were within $8.12 \%$ and $8.46 \%$ of the total fatty acids. These were represented by palmitic acid, which was the predominant SFAs and ranged from $4.68-5.08 \%$, followed by stearic acid (1.60-1.82\%), margaric acid (1.03-1.18\%), arachidic acid $(0.37-0.41 \%)$, and behenic acid $(0.12-0.20 \%)$. Freeze dried seeds of SB contained significantly lower palmitic acid (4.68\%) than the rest of the oil samples (4.95-5.08\%). A high level of palmitic acid in the oil is undesirable because it raises these low density lipoprotein (LDL) levels and enhances the risk of cardiovascular diseases. The monounsaturated fatty acids (MUFAs) accounted for 7.18-8.17\% of the total fatty acids. Only two MUFAs were identified: cis-oleic acid (6.78-7.76\%) and trans-oleic acid (0.40-0.43\%). Among the samples, oil from HF and SB oven dried seeds, exhibited the highest cis-oleic acid (7.45 and 7.76\%, respectively). Literature has reported that MUFAs are associated with the prevention of coronary heart diseases, colon, breast, and skin cancer [40]. 
The polyunsaturated fatty acids, which make up most of the fatty acids in pomegranate seed oil, varied from $82.13-83.81 \%$. Generally, all oil samples exhibited high levels of punicic acid (81.21-82.68\%). These findings are quite encouraging, as high levels of punicic acid in SB would make the oil a valuable ingredient in cosmetology. The level of punicic acid in the current study was higher than the one reported by Zaouay et al. [39] in oil extracted from seeds of cracked and intact pomegranates. Punicic acid presents several potential health benefits such as cholesterol lowering, antidiabetic, antioxidant, anti-inflammatory, and anticarcinogenic properties ([41]. Alpha-linolenic acid (0.18-0.21\%) and $\gamma$-linolenic

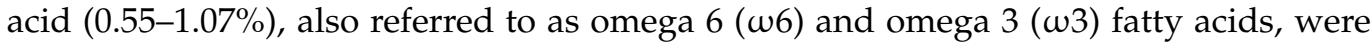
identified among the PUFAs but in minor concentrations. The essential fatty acids are crucial in maintaining the physiological functions of the human body. The $\omega 6 / \omega 3$ ratio is valuable in explaining the effect of dietary PUFAs on the pathogenesis of cardiovascular diseases, cancer, inflammatory and autoimmune disorders [42]. Generally, a high $\omega 6 / \omega 3$ ratio is regarded as harmful to human health, whereas a value around 1 is considered healthier and protective against such chronic diseases. Although they significantly differed among the oil samples, $\omega 6 / \omega 3$ ratios $(0.19-0.37 \%)$ in the current study were low among all samples, suggesting that the oil samples were healthy. The MUFA/PUFA (0.09-0.10\%) and SFA/UFA ratios (10.57-11.21\%) were not significantly affected by fruit quality and seed drying methods.

\subsection{Principal Component Analysis}

Due to the numerous variables and factors analysed, principal component analysis (PCA) was conducted to reduce the dimensionality of the data and improve its interpretation (Figure 3). F1 and F2 represented the highest eigenvalues (8.0 and 6.4, respectively) and accounted for $62.39 \%$ of the total variability $(\mathrm{F} 1=34.71 \%$ and $\mathrm{F}=27.68 \%)$. The components, as shown in Figure 3, indicate a number of factors. F1 was positively correlated with TPC (0.728), IC ${ }_{50} \mathrm{DP}(0.812)$, punicic acid (0.873), PUFAs (0.818), and UFA/SFA ratio (0.743), whilst it was negatively associated with oil yield $(-0.805)$ and saturated fatty acids, including palmitic acid (-0.736), stearic acid (-0.872), and arachidic acid ( -0.794$)$. At the same time, F1 was positively associated with oil from freeze dried seeds of SB, while it was negatively correlated with oil from oven dried seeds of HF. These results suggest that oven drying seeds from HF facilitated high oil yield; however, the oil contained high levels of palmitic acid, making it undesirable among seed oil consumers. From a cosmetology perspective, the oil extracted from freeze dried seeds of SB could be a potential ingredient for the formulation of skincare products due to high levels of TPC and punicic acid. F2 was positively correlated with cis-oleic acid (0.955) and MUFAs (0.961), whilst it was negatively associated with AV (-0.781), $\mathrm{IC}_{50} \mathrm{DPPH}(-0.781)$ and behenic acid ( -0.875$)$. Concomitantly, F2 positively corresponded with oil from oven dried seeds of SB but negatively corresponded with oil from freeze dried seeds of HF. This points out that oil from oven dried seeds of SB is also a good source of compounds (cis-oleic acid) with LDL cholesterol reducing properties. Interestingly, oil from freeze dried seeds of HF possessed poor antiradical activity against DPPH assay and tyrosinase inhibition activity, which correlates with high levels of $\rho$-anisidine value in the respective oil samples. Nonetheless, oil from sun-dried seeds, both of HF and SB, were not adequately represented in the F1 and F2 principal components. 


\section{Biplot (axes F1 and F2: 62,39 \%)}

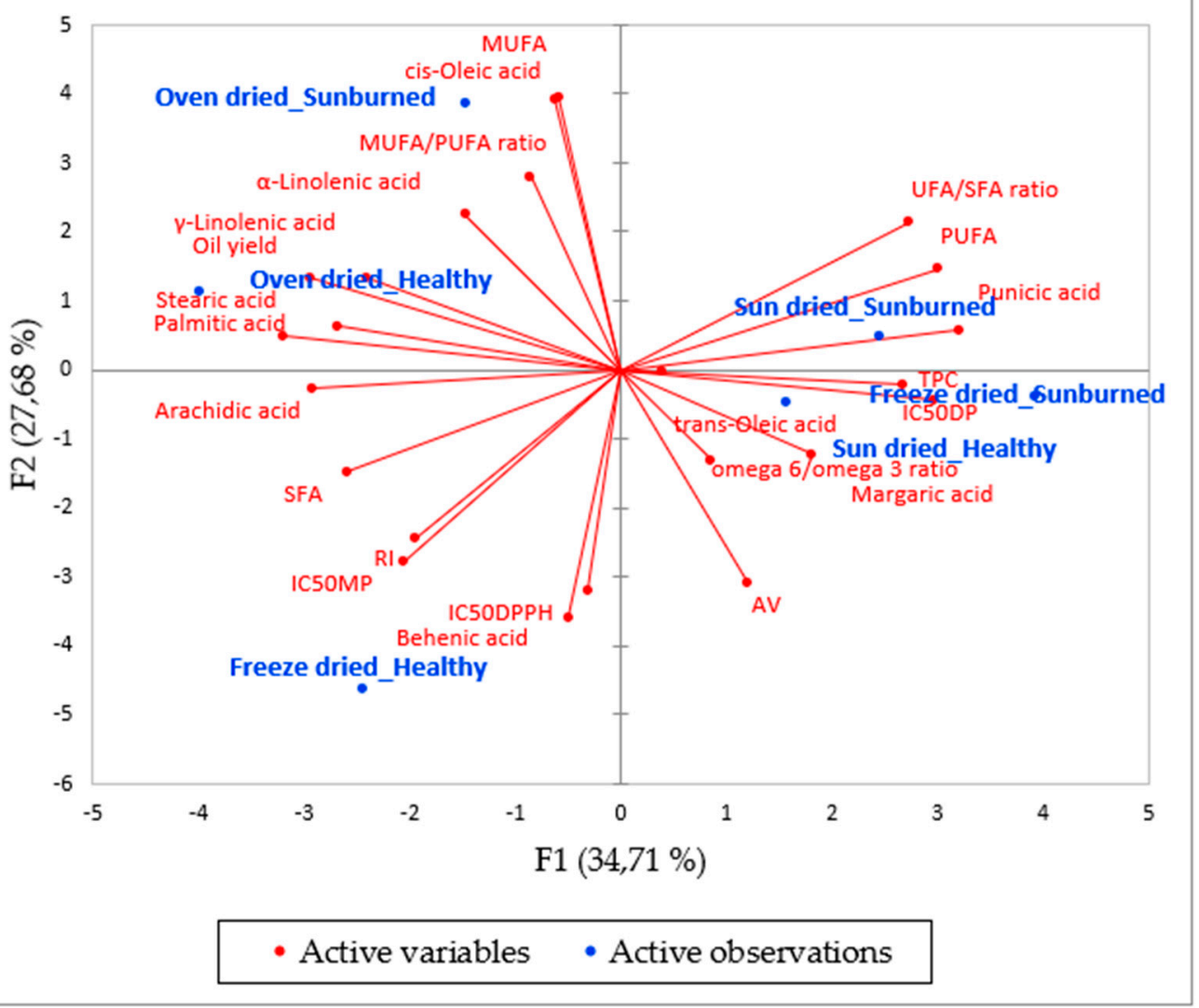

Figure 3. Principal component analysis (PCA) showing the relationship between fruit quality, seed drying method, and the oil chemical properties. TPC: total phenolic content, $\mathrm{IC}_{50} \mathrm{DP}$ : diphenolase, $\mathrm{IC}_{50} \mathrm{MP}$ : monophenolase, $\mathrm{IC}_{50} \mathrm{DPPH}, \mathrm{RI}$ : refractive index, $\mathrm{AV}$ : anisidine value, $\mathrm{IC}_{50}-50 \%$ inhibitory concentration, SFA: saturated fatty acids, MUFA: monounsaturated fatty acids, PUFA: polyunsaturated fatty acids, UFA: unsaturated fatty acids.

\section{Conclusions}

Apart from refractive index and fatty acid composition, oil from the seeds of SB fruits significantly differed from the oil from seeds of HF. Moreover, the seed drying method was implicated in the oil quality. Oven drying the seeds produced the highest oil yield; however, the oil contained more saturated fatty acids. Freeze dried seeds of SB is an interesting source of oil with higher TPC, punicic acid, PUFAs, and UFA/SFA ratios. Furthermore, oil from oven dried seeds of SB showed higher monounsaturated fatty acids and cis-oleic acid making it a good source of compounds with LDL cholesterol reducing properties. It can be concluded that seeds from SB present a great potential for application in cosmetic product formulation. Overall, the findings of this study present a significant opportunity to enhance the value of pomegranates, reduce postharvest wastes, and keep pomegranates competitive among other fruits.

Author Contributions: O.A.F., conceptualization; O.A.F. and T.K., writing-review and editing; O.A.F. and U.L.O., funding acquisition, supervision and validation; O.A.F. and T.K., investigation, methodology, visualization, formal analysis, and writing-original draft. All authors have read and agreed to the published version of the manuscript.

Funding: This work is based on the research supported wholly or in part by the National Research Foundation (NRF) of South Africa (Grant Numbers: 64813 and 129295). The opinions, findings, and conclusions or recommendations expressed are those of the author(s) alone, and the NRF accepts no liability whatsoever in this regard. 
Institutional Review Board Statement: Not applicable.

Informed Consent Statement: Not applicable.

Data Availability Statement: Not applicable.

Conflicts of Interest: The authors declare that they have no conflict of interest.

\section{Abbreviations}

$\begin{array}{ll}\text { ANOVA } & \text { Analysis of Variance } \\ \text { AV } & \text { Anisidine value } \\ \text { DPPH } & \text { 2.2-diphenyl-1-picryl hydrazyl } \\ \text { FA } & \text { Fatty acid } \\ \text { FD } & \text { Freeze dried } \\ \text { FRAP } & \text { Ferric reducing antioxidant power } \\ \text { GAE } & \text { Gallic acid equivalence } \\ \text { GC-MS } & \text { Gas chromatograph mass spectroscopy } \\ \text { HF } & \text { Healthy fruit } \\ \text { IC } 50 & \text { 50\% inhibitory concentration } \\ \text { LDL } & \text { Low density lipoprotein } \\ \text { MIC } & \text { Minimum inhibitory concentration } \\ \text { MUFA } & \text { Monounsaturated fatty acid } \\ \text { PCA } & \text { Principal component analysis } \\ \text { PS } & \text { Pomegranate seed } \\ \text { PSO } & \text { Pomegranate seed oil } \\ \text { PUFA } & \text { Polyunsaturated fatty acid } \\ \text { RI } & \text { Refractive index } \\ \text { SB } & \text { Sun burned } \\ \text { SD } & \text { Sun dried } \\ \text { SFA } & \text { Saturated fatty acid } \\ \text { TEAC } & \text { Trolox equivalence antioxidant capacity } \\ \text { TPC } & \text { Total phenolic content } \\ \text { UFA } & \text { Unsaturated fatty acid } \\ & \end{array}$

\section{References}

1. Fawole, A.O.; Makunga, N.P.; Opara, U.L. Antibacterial, antioxidant and tyrosinase-inhibition activities of pomegranate fruit peel methanolic extract. BMC Complement. Altern. Med. 2012, 12, 200. [CrossRef]

2. Eikani, M.H.; Golmohammad, F.; Saied, S. Extraction of pomegranate (Punica granatum L.) seed oil using superheated hexane. Food Bioprod. Process. 2012, 90, 32-36. [CrossRef]

3. Caligiani, A.; Bonzanini, F.; Palla, G.; Cirlini, M.; Bruni, R. Characterization of a Potential Nutraceutical Ingredient: Pomegranate (Punica granatum L.) Seed Oil Unsaponifiable Fraction. Plant Foods Hum. Nutr. 2010, 65, 277-283. [CrossRef]

4. Koba, K.; Yanagita, T. Potential health benefits of pomegranate (Punica granatum L.) seed oil containing conjugated linolenic acid. In Nuts $\mathcal{E}$ Seeds in Health and Disease Prevention; Preedy, V., Watson, R., Patel, V., Eds.; Academic Press: Cambridge, MA, USA, 2012; pp. 919-924.

5. Pomegranate Association of South Africa (POMASA). Pomegranate Industry Overview. South Africa. 2020, pp. 1-16. Available online: https: / / www.sapomegranate.co.za/statistics-and-information/pomegranate-industry-overview/ (accessed on 4 September 2021).

6. Fawole, O.A.; Opara, U.L. Value-addition of sunburned pomegranate fruit to reduce postharvest losses: A cosmeceutical perspective. Acta Hortic. 2018, 225, 221-226. [CrossRef]

7. Opara, I.K.; Fawole, O.A.; Kelly, C.; Opara, U.L. Quantification of on-farm pomegranate fruit postharvest losses and waste, and implications on sustainability indicators: South African case study. Sustainability 2021, 13, 5168. [CrossRef]

8. Wittich, K.P. Apple sunburn risk detection-A simple model for agricultural decision making and some fruit temperature measurements. Erwerbs-Obstbau 2021, 63, 25-36. [CrossRef]

9. Racsko, J.; Schrader, L.E. Sunburn of apple fruit: Historical background, recent advances, and future perspectives. Crit. Rev. Plant Sci. 2021, 31, 455-504. [CrossRef]

10. Caleb, O.J.; Opara, U.L.; Witthuhn, C. Modified atmosphere packaging of pomegranate fruit and arils: A review. Food Bioproc. Technol. 2021, 5, 15-30. [CrossRef]

11. Kaseke, T.; Opara, U.L.; Fawole, O.A. Fatty acid composition, bioactive phytochemicals, antioxidant properties and oxidative stability of edible fruit seed oil: Effect of preharvest and processing factors. Heliyon 2020, 6, e04962. [CrossRef] [PubMed] 
12. Al Juhaimi, F.; Özcan, M.M.; Uslu, N.; Ghafoor, K. The effect of drying temperatures on antioxidant activity, phenolic compounds, fatty acid composition and tocopherol contents in citrus seed and oils. J. Food Sci. Technol. 2018, 55, 190-197. [CrossRef]

13. Irondi, A.E.; Anokam, K.K.; Ndidi, U.S. Effect of drying methods on the phytochemical composition and antioxidant activities of Carica papaya seed. Int. J. Biosci. 2013, 11, 154-163.

14. Dorta, E.; Lobo, M.G.; González, M. Using drying treatments to stabilise mango peel and seed: Effect on antioxidant activity. LWT-Food Sci. Technol. 2012, 45, 261-268. [CrossRef]

15. Saavedra, J.; Cordova, A.; Navarro, R.; Díaz-Calderon, P.; Fuentealba, C.; Astudillo-Castro, C.; Toledo, L.; Enrione, J. Industrial avocado waste: Functional compounds preservation by convective drying process. J. Food Eng. 2017, 198, 81-90. [CrossRef]

16. Teles, A.S.C.; Chávez, D.W.H.; Gomes, F.S.; Cabral, L.M.C.; Tonon, R.V. Effect of temperature on the degradation of bioactive compounds of pinot noir grape pomace during drying. Braz. J. Food Technol. 2018, 21, 1-7. [CrossRef]

17. AOCS Official Method Cd 18-90, $\rho$-anisidine value. In Official Methods and Recommended Practices of the American oil Chemists Society; Firestone, D., Ed.; AOCS Press: Champaign, IL, USA, 2003.

18. Jakopic, J.; Petkovsek, M.M.; Likozar, A.; Solar, A.; Stampar, F.; Veberic, R. HPLC-MS identification of phenols in hazelnut (Corylus avellana L.) kernels. Food Chem. 2011, 124, 1100-1106. [CrossRef]

19. Fawole, O.A.; Opara, U.L. Seasonal variation in chemical composition, aroma volatiles and antioxidant capacity of pomegranate during fruit development. Afr. J. Biotechnol. 2013, 12, 4006-4019.

20. Kaseke, T.; Opara, U.L.; Fawole, O.A. Effect of blanching pomegranate seed on physicochemical attributes, bioactive com-pounds, and antioxidant activity of extracted oil. Molecules 2020, 25, 2554. [CrossRef]

21. Ahangari, B.; Sargolzaei, J. Extraction of pomegranate seed oil using subcritical propane and supercritical carbon dioxide 1. Theor. Found. Chem. Eng. 2012, 46, 258-265. [CrossRef]

22. Tian, Y.; Xu, Z.; Zheng, B.; Lo, Y.M. Ultrasonics Sonochemistry Optimization of ultrasonic-assisted extraction of pomegranate (Punica granatum L.) seed oil. Ultrason. Sonochem. 2013, 20, 202-208. [CrossRef]

23. Omosuli, S.V.; Oloye, D.A.; Ibrahim, T.A. Effect of drying methods on the physicochemical properties and fatty acid composition of moringa seeds oil. Arch. Food Nutr. Sci. 2017, 1, 27-32.

24. Taiwo, A.A.; Agbotoba, M.O.; Oyedepo, J.A.; Shobo, O.A.; Oluwadare, I.; Olawunmi, M.O. Effects of drying methods on properties of watermelon (Citrullus lanatus) seed oil. Afr. J. Food, Agric. Nutr. Dev. 2008, 8, 492-501. [CrossRef]

25. Khoddami, A.; Bin, Y.; Man, C.; Roberts, T.H. Physicochemical properties, and fatty acid profile of seed oil from pomegranate (Punica granatum L.) extracted by cold pressing. Eur. J. Lipid Sci. Technol. 2014, 116, 553-562. [CrossRef]

26. Ogrodowska, D.; Tańska, M.; Brandt, W. The Influence of Drying Process Conditions on the Physical Properties, Bioactive Compounds and Stability of Encapsulated Pumpkin Seed Oil. Food Bioproc. Technol. 2017, 10, 1265-1280. [CrossRef]

27. Zhang, Z.; Liu, Y.; Che, L. Effects of different drying methods on the extraction rate and qualities of oils from demucilaged flaxseed. Dry. Technol. 2018, 36, 1642-1652. [CrossRef]

28. Jahurul, M.H.A.; Ying, L.N.; Amir, H.M.S.; Azzatul, F.S.; Sharifudin, M.S.; Hasmadi, M.; Lee, J.S.; Mansoor, A.H.; Jumardi, R.; Matanjun, P.; et al. Effects of drying methods on the characteristics of rambutan (Nephelium lappaceum L.) seed fat: An optimisation approach. Eng. Rep. 2021, 1, e12050. [CrossRef]

29. Pande, G.; Akoh, C.C. Antioxidant capacity and lipid characterization of six Georgia-grown pomegranate cultivars. J. Agric. Food Chem. 2009, 57, 9427-9436. [CrossRef]

30. Costa, A.M.M.; Silva, L.O.; Torres, A.G. Chemical composition of commercial cold-pressed pomegranate (Punica granatum) seed oil from Turkey and Israel, and the use of bioactive compounds for samples' origin preliminary discrimination. J. Food Compost. Anal. 2019, 75, 8-16. [CrossRef]

31. Bualuang, O.; Onwude, D.; Uso, A.; Peerachaakkarachai, K.; Mora, P.; Dulsamphan, S.; Sena, P. Determination of drying kinetics, some physical, and antioxidant properties of papaya seeds undergoing microwave vacuum drying. J. Food Process. Eng. 2018, 43 , e13176. [CrossRef]

32. Araujoa, R.G.; Rodriguez-Jassoa, R.M.; Ruiza, H.A.; Govea-Salasb, M.; Pintadoc, M.E.; Aguilara, C.N. Process optimization of microwave-assisted extraction of bioactive molecules from avocado seeds. Ind. Crop. Prod. 2014, 154, 112623. [CrossRef]

33. Masuda, M.; Murata, K.; Fukuhama, A.; Naruto, S.; Fujita, T.; Uwaya, A.; Isami, F.; Matsuda, H. Inhibitory effects of constituents of Morinda citrifolia seeds on elastase and tyrosinase. J. Nat. Med. 2009, 63, 267-273. [CrossRef]

34. Xu, Y.; Fan, M.; Ran, J.; Zhang, T.; Sun, H.; Dong, M.; Zhang, Z.; Zheng, H. Variation in phenolic compounds and antioxidant activity in apple seeds of seven cultivars. Saudi J. Biol. Sci. 2016, 23, 379-388. [CrossRef]

35. De Melo, I.L.P.; de Carvalho, E.B.T.; Silva, A.M.O.; Yoshime, L.T.; Sattler, J.A.G.; Pavan, R.T.; Mancini-Filho, J. Characterization of constituents, quality, and stability of pomegranate seed oil (Punica granatum L.). Food Sci. Technol. 2014, 36, 132-139. [CrossRef]

36. Sarikurkcu, C.; Zengin, G.; Oskay, M.; Uysal, S.; Ceylan, R.; Aktumsek, A. Composition, antioxidant, antimicrobial and enzyme inhibition activities of two origanum vulgare subspecies (subsp. vulgare and subsp. hirtum) essential oils. Ind. Crop. Prod. 2015, 70, 178-184. [CrossRef]

37. Othman, L.; Sleiman, A.; Abdel-Massih, R.M. Antimicrobial activity in Middle Eastern plants. Front. Microbiol. 2019, 10, 911. [CrossRef] 
38. Alqahtani, F.Y.; Aleanizy, F.S.; Mahmoud, A.Z.; Farshori, N.N.; Alfaraj, R.; Al-sheddi, E.S.; Alsarra, I.A. Chemical composition and antimicrobial, antioxidant, and anti-inflammatory activities of Lepidium sativum seed oil. Saudi J. Biol. Sci. 2019, 26, 1089-1092. [CrossRef]

39. Zaouay, F.; Brahem, M.; Boussaa, F.; Haddada, F.M.; Tounsi, M.S.; Mars, M. Effects of fruit cracking and maturity stage on quality attributes and fatty acid composition of pomegranate seed oils. Int. J. Fruit Sci. 2020, 20, 1959-1968. [CrossRef]

40. Prabakaran, M.; Lee, K.J.; An, Y.; Kwon, C.; Kim, S.; Yang, Y.; Ahmad, A.; Kim, S.H.; Chung, M. Changes in soybean (Glycine max L.) flour fatty-acid content based on storage temperature and duration. Molecules 2018, 23, 2713. [CrossRef]

41. Aruna, P.; Venkataramanamma, D.; Singh, A.K.; Singh, R.P. Health benefits of punicic acid: A review. Compr. Rev. Food Sci. Food Saf. 2016, 15, 16-27. [CrossRef] [PubMed]

42. Cicero, N.; Albergamo, A.; Salvo, A.; Bua, G.D.; Bartolomeo, G.; Mangano, V.; Rotondo, A.; Di Stefano, V.; Di Bella, G.; Dugo, G. Chemical characterization of a variety of cold-pressed gourmet oils available on the Brazilian market. Food Res. Int. 2018, 109, 517-525. [CrossRef] [PubMed] 